\title{
Histidines 13 and 14 in the $A \beta$ sequence are targets for inhibition of Alzheimer's disease $A \beta$ ion channel and cytotoxicity
}

\author{
JUAN CARLOS DÍAZ, JOHN LINNEHAN, HARVEY POLLARD \\ and NELSON ARISPE
}

Department of Anatomy, Physiology and Genetics, and Institute for Molecular Medicine, Uniformed Services University School of Medicine, USUHS, Bethesda, Maryland, USA

\begin{abstract}
The fact that Alzheimer's beta amyloid (A $\beta$ ) peptides forms cation channels in lipid bilayers was discovered during the course of our experiments in the laboratory of "Guayo" Rojas at NIH in Bethesda, Maryland (USA). Recently, we found that the $A \beta$ ion channel could be blocked selectively with small peptides that copy the amino acid sequence of the predicted mouth region of the $A \beta$ channel pore. We now have searched for the essential amino acid residues required for this blocking effect by mutations. We found that the ability of peptides to block $\mathrm{A} \beta$ channel activity could be lost by replacement of histidines 13 and 14 by alanine or lysine. The amino acid substitution also resulted in the loss of the capacity of the peptides to protect cells from A $\beta$ cytotoxicity. These data thus contribute to the definition of the region of the $A \beta$ sequence that participates in the formation of the channel pore. Additionally, these data support the hypothesis that the ion channel activity of A $\beta$ contributes significantly to the cytotoxic properties of $\mathrm{A} \beta$. These data also emphasize the potential value in using inhibition of A $\beta$ ion channel activity as an end point for Alzheimer's disease drug discovery.
\end{abstract}

Key terms: Alzheimer's disease, beta amyloid, ion channel blockers, peptides, histidine, toxicity.

\section{PROLOGUE}

During Eduardo “Guayo” Rojas' expansive life, he carved out a mayor place in the history of science. As science has no borders, neither had Guayo: of the many characteristics of this talented man, one of my favorites is that he could go anywhere to do science and feel at home with anyone. Indeed, Guayo has set foot in many laboratories throughout the world, collaborating with scientists from a wide range of ethnic and racial backgrounds. His individual characteristics, extensive enthusiasm, skill and knowledge resulted in publications in numerous journals of international repute with collaborators of almost any racial origins. I deem myself one of the many fortunate people who have crossed his path at different latitudes.
Sharing those moments with Guayo has been for me extremely valuable. Away from the classroom formalities, he taught me to set up a laboratory, build my own tools and to be creative at doing dynamic science. I would tease him by saying that his favorite pastime was putting together and taking apart laboratories. It is my pleasure to pay this tribute and acknowledge Guayo as a great scientist, person and friend, since without doubt he crafted a very important part of my professional life.

$$
\text { N. Arispe }
$$

\section{INTRODUCTION}

The beta amyloid (A $\beta$ ) peptide associated with Alzheimer's disease (AD) interacts with neurons to generate an increase in the 
intracellular calcium concentration. If the imbalance of the calcium homeostasis were sufficiently large, the neuron may die, and this effect has been proposed to mediate neurotoxicity (Mattson et al., 1992). We have proposed that the mechanism of the intracellular calcium increase is by the $A \beta$ peptide itself forming an independent channel and conducting the calcium into the cell (Arispe et al., 1993a, 1993b, 1996). Ion channel formation by $A \beta$ has been confirmed in a variety of membranes by many others over the past decade (Galdzicki et al., 1994; Kawahara et al., 1997; Rhee et al., 1998; Lin et al., 1999, 2001; Hirakura et al., 1999; Vargas et al., 2000; Kourie et al., 2001; Lin and Kagan, 2002; Bahadi et al., 2003; Micelli et al., 2004; Maurits et al., 2005; Mendes et al., 2005). The consequence of this concerted study has been strong support for what the initial discovery team of Rojas ("Guayo"), Arispe and Pollard termed the "ion channel hypothesis" for AD (Arispe et al., 1994a, 1994b; Pollard et al., 1995).

Theoretical methods have been used to develop models for the ion channel structure of the membrane-bound A $\beta$ (Durell et al., 1994). Experimental support for some of these theoretical models has come from Atomic Force Microscope (AFM) amplitude mode images of $A \beta$ reconstituted in membranes and from studies of the interaction of $\mathrm{Zn}^{2+}$ ions with $A \beta$ channels. The polymeric conformation of membrane-bound $A \beta$ subunits has been confirmed by the channel-like oligomeric structures observed in the AFM images of $\mathrm{A} \beta$ reconstitute in planar lipid bilayers (Lin et al., 2001, Quist et al., 2005).

The orientation of $A \beta$ in the membrane has been deduced to be asymmetric due the fact that $\mathrm{Zn}^{2+}$ preferentially binds and blocks only one side of the channel (Arispe et al., 1996; Vargas et al., 2000). We recently showed that peptide segments containing histidines 13 and 14 , chosen from regions around the putative mouth of the polymeric membrane-bound $A \beta$ channel model, effectively block the channel activity in planar lipid bilayers (Arispe, 2004). The active peptides blocked asymmetrically, as previously demonstrated for $\mathrm{Zn}^{2+}$ (Arispe et al., 1996),

In different metalloproteases, sites rich in histidines and anionic residues have been associated with $\mathrm{Zn}^{2+}$ binding. Consistently, least energy calculations for $A \beta$ model construction indicate a ring of histidine residues around the entrance of the putative pore (Durell et al., 1994), and the active peptides that asymmetrically block $A \beta$ channels include a histidine dyad $(\mathrm{H}-\mathrm{H})$ that we previously have modeled to be at the mouth of the pore. These facts strongly suggest that the sites rich in histidine in the $\mathrm{A} \beta$ sequence are associated with the $A \beta$ ion channel property. This investigation has the dual purpose of testing the hypothesis that the histidine residues 13 and 14 are in the ion conductance path; and secondly, of testing the hypothesis that the toxicity of $\mathrm{A} \beta$ on cells is exerted basically through the capacity of $A \beta$ to form ion channels in the cell surface membrane.

\section{MATERIALS AND METHODS}

The methods used here have been described previously (Arispe and Doh, 2002; Arispe, 2004). The $A \beta$ channel incorporation into the phospholipid membranes was achieved indirectly by fusion of A $\beta$-carrying proteoliposomes with planar phospholipid bilayers.

\section{Preparation of proteoliposomes}

Liposomes were prepared by hydration of air-dried palmitoyloleoyl phosphatidylserine $(10 \mathrm{mg})$ with $1 \mathrm{M}$ potassium aspartat $\varphi, \mathrm{H}$ 7.0 (1 ml), followed by water sonication for $5 \mathrm{~min}$. The liposomesuspension $(50 \mu \mathrm{l})$ was mixed with a stock aqueous solution of $\mathrm{Ab}$ ( $1 \mathrm{mg} / \mathrm{ml}$, obtained from Bachem and from AnaSpec, California, USA), followed by sonication for an additional period of $2 \mathrm{~min}$. An aliquot $(5 \mu \mathrm{l})$ of the proteoliposome suspension was added to the solution in the cis side of the planar lipid bilayer chamber and stirred. After successful ion channel incorporation was achieved, proteoliposomes were perfused from the chamber prior to test peptide addition. 


\section{Planar lipid bilayer methodology}

Planar lipid bilayers were made as described (Arispe et al., 1993a). Briefly, a suspension of palmitoyloleoyl phosphatidylserine and palmitoyloleoyl phosphatidylethanolamine, 1 : 1 , in n-decane was prepared. This suspension was applied to an orifice of about 100-120 $\mu \mathrm{m}$ in diameter with a Teflon ${ }^{\mathrm{TM}}$ film separating two compartments, $1.2 \mathrm{ml}$ volume each. The ionic solutions in the compartments contained asymmetrical concentrations of $\mathrm{CsCl}\left(200_{\text {cis }} / 50_{\text {trans }} \mathrm{mM}\right)$ and symmetrical $0.5 \mathrm{mM} \mathrm{CaCl}$ and $5 \mathrm{mM}$ K-HEPES, pH 7. The two ionic compartments were connected electrically via agar bridges and $\mathrm{Ag} / \mathrm{AgCl}$ pellet electrodes to the input of a voltageclamp amplifier. Current was recorded using a patch-clamp amplifier (Axopatch-1D equipped with a low noise (CV-4B) headstage; Axon Instruments, Foster City, $\mathrm{CA}$ ), and data were stored on computer disk memory. Off-line analysis of the channel activity was carried out using the software package Pclamp (Axon Instruments, Foster City, CA).

\section{Peptide synthesis}

We have synthesized 5 peptides segments from the A $\beta$ sequence. NA7, NA12, NA13, NA14, and NA15 are made of seven residues with the following sequences: EVHHQKL, EVAHQKL, EVAAQKL, EVKHQKL, and EVKKQKL, respectively. These peptides were synthesized in the Biomedical Instrumentation Center at the Uniformed Services University of the Health Sciences, Bethesda, MD, utilizing an Applied Biosystems model 433A peptide synthesizer. The chemistry used to produce the peptides was the HBTU/DIEA activation of Fmoc amino acids. The purity of the peptides was confirmed by HPLC, and an automatic protein sequencer, Applied Biosystems model 476, confirmed the sequence. To test the effect of the peptides on the $A \beta$ ion channel, aliquots of $6 \mu \mathrm{l}$ of peptide stock solution $(1 \mathrm{mg} / \mathrm{ml})$ were added to one side of the chamber, and the electrical activity was monitored. If no effect was observed after a reasonable period of time, the peptide was studied on the other side of the chamber.

\section{Cell culture and viability}

PC12 cells, derived from a transplantable rat pheochromocytoma (ATCC \# CRL 1721), were cultured in ATCC medium: Ham's F12K medium (2 mM L-glutamine adjusted to contain $1.5 \mathrm{~g} / \mathrm{L}$ sodium bicarbonate, $82.5 \%$; horse serum, $15 \%$; fetal bovine serum, $2.5 \%$ ) and subcultured in 24-well culture plates for viability tests. To quantify the cytotoxicity of $\mathrm{A} \beta$, a colorimetric XTT assay (Cell Proliferation Kit II from Roche Molecular Biochemicals, Mannheim, Germany) was utilized. This metabolic activity assay frequently is used to measure factor-induced cytotoxicity. In our experiments this assay was applied after cells had been exposed to $A \beta$ and the floating dead cells removed. PC12 cells subcultured in 24well plates were exposed to different concentrations of the test peptides. To determine cell viability, the colorimetric assay was applied after the given time of incubation in the presence of the $A \beta$ and the test peptides, and the results were expressed as a percentage of surviving control cells.

\section{RESULTS}

Peptides have been synthesized that match segments of the sequences of the proposed $A \beta$ pore region

As shown in Figure 1A, the predicted pore region of $A \beta$ (Durell et al., 1994) is made of the arms of the hydrophilic $\beta$-hairpin structure composed of residues 1 to 16 . The structure that is formed by a radial polymer of $A \beta$ subunits predicts three rings of histidine residues. These three rings surround and form the path for the ions passing through the $A \beta$ pore. Two of those histidine rings asymmetrically gate one of the pore's entrances.

To test the hypothesis that these histidine rings gate the $\mathrm{A} \beta$ ion channel, the test peptides were constructed with native and mutant residues based on segments proposed to form one putative mouth of the pore. The results from our previous work (Arispe, 2004) show that the common feature in the active $A \beta$ channel blocker 
peptides is that they all possess in their sequence the two histidine residues modeled to line the entry to the $A \beta$ pore. Figure 1B shows the sequence of an $A \beta 42$ subunit and indicates the corresponding residues in five test peptides. Peptide NA7 was constructed with the native sequence of $\mathrm{A} \beta_{11-17}$, which includes the two histidines residues 13 and 14 (EVHHQKL). To test the participation of histidine residues in $\mathrm{A} \beta$ channel function, we substituted histidine residues with either the non-polar alanine (peptide NA12 and peptide NA13) or with the lysine residues (peptide NA14 and peptide NA15) in the sequence of $A \beta_{11-17}$ as follows: EVAHQKL, EVAAQKL, EVKHQKL, and EVKKQKL, respectively. Lysine is a basic amino acid, like histidine, but lacks the imidazole groups on the side chain.
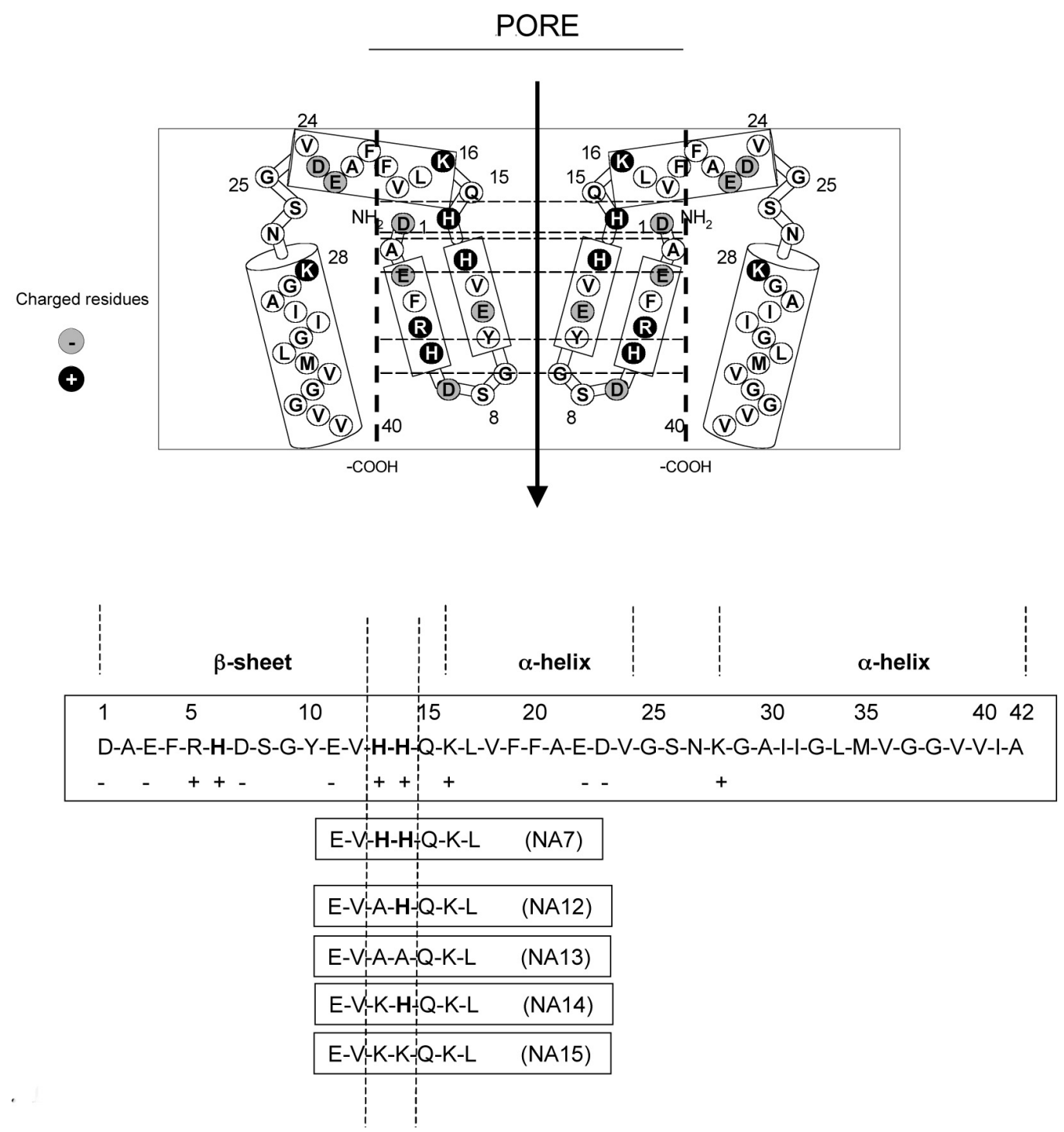

Figure 1. Theoretical model of a membrane-bound $A \beta$ ion channel modified from Durell et al., 1994. A: Two A $\beta$ subunits have been placed in a two dimensional array in order to illustrate the formation of a hydrophilic pore. The dotted line, at the levels of histidine 6,13 and 14, point out the formation of three histidine rings encircling the path for the ions passing through the $A \beta$ pore. B: The five test peptides (boxes) have been laid next to the homologous regions of the $A \beta$ sequence to illustrate the corresponding residues and the position of the substitutions. 
The native sequence peptide NA7 blocks $A \beta$ channel conductance

As shown in Figure 2, ionic currents are recorded after the incorporation of $\mathrm{A} \beta \mathrm{P}$ (1$40)$ into planar lipid membranes, confirming that $\mathrm{A} \beta$ forms cation-selective channels. The two current records in Figure 2 display ten seconds of activity from an $\mathrm{A} \beta$ channel incorporated in a lipid bilayer that was maintained at zero membrane potential. Upward deflections of current traces represent a flow of $\mathrm{Cs}^{+}$from the trans to the cis side, since the planar lipid bilayer is separated by asymmetrical $\mathrm{CsCl}$ solutions $(50 \mathrm{mM} \mathrm{CsCl}$ on the cis side and $200 \mathrm{mM} \mathrm{CsCl}{ }_{2}$ in the trans side). Although no transmembrane electrical potential was imposed, the chemical potential drives discrete jumps of current to different levels

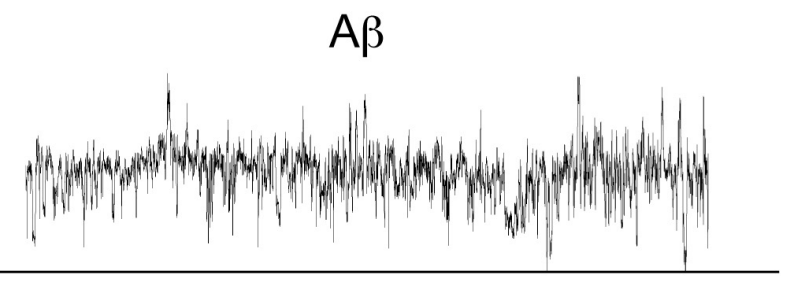

$$
A \beta+N A 7
$$
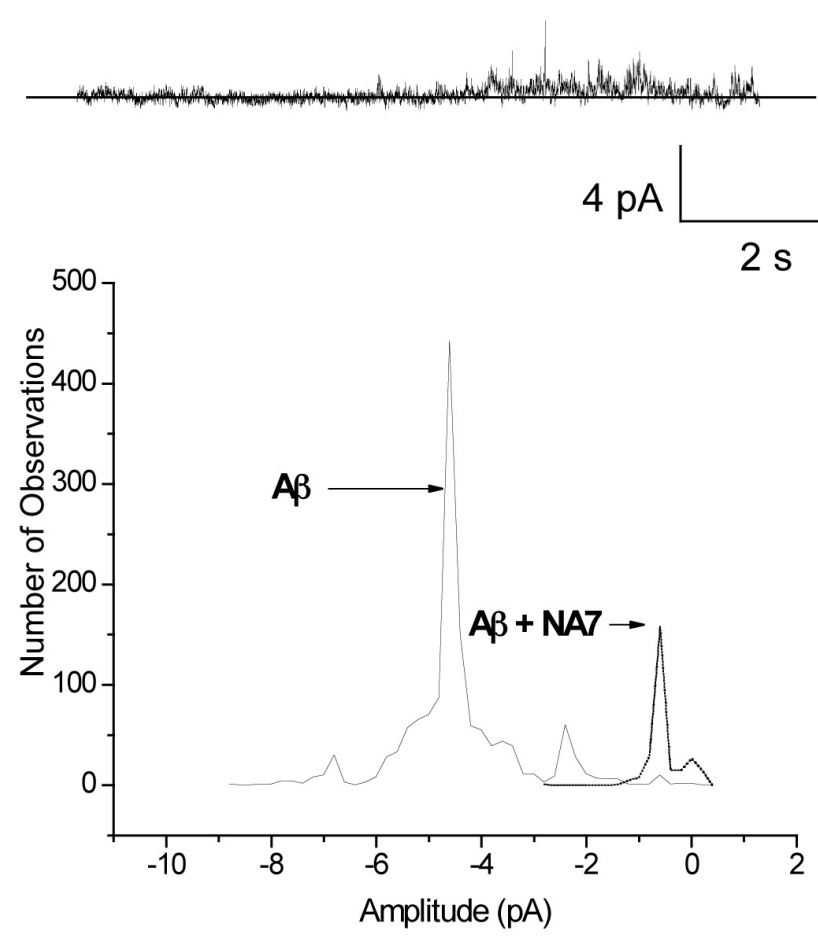

Figure 2. NA7 irreversibly blocks the membrane-bound A $\beta$ ion channel. Electrical activity across a lipid bilayer with incorporated $A \beta$ ion channel, recorded before (top record) and in the presence of NA7 (bottom record). The membrane electrical potential in the experiment was maintained at zero level. The bottom panel displays a current amplitude histogram of the channel activity in the current traces shown above. Four main current peaks of $0.5,2.3,4.5$ and $6.8 \mathrm{pA}$ characterize the A $\beta$ channel activity. After the addition of NA7, only the smallest peak, ca. $0.5 \mathrm{pA}$, remains before the trace becomes electrically silent. 
throughout the upper control record. Two minutes after the addition of the peptide NA7 $(7 \mu \mathrm{M})$ to the cis compartment, the peaks of current observed in the upper control record became electrically silent, indicating that the $A \beta$ ion channel electrical activity had been blocked by NA7. An amplitude histogram of the current events of the channel activity recorded before the addition of NA7 shows four main current peaks of $0.5,2.3,4.5$ and $6.8 \mathrm{pA}$ in the control conditions. After the addition of NA7, only current events of the smallest amplitude, ca. $0.5 \mathrm{pA}$, were observed just before the electrical recording became silent.

A $\beta$ channel conductance is blocked partially by the mutant peptides NA12 and NA14 that contain only one histidine

Peptides NA12 and NA14 have similar sequences to NA7 except that histidine 13 has been replaced by either alanine (peptide NA12; H13A) or lysine (peptide NA14; $\mathrm{H} 13 \mathrm{~K}$ ). Both peptides were found to be only partially $A \beta$ ion channel blockers, as can be seen in the experiments depicted in Figures 3 and 4 . The experiment displayed in Figure 3 illustrates the reduction in the number of the larger peaks of ionic current from an $A \beta$ channel incorporated in lipid bilayer at zero membrane potential after the addition of peptide NA12 (H13A) $(7 \mu \mathrm{M})$ to the cis compartment. The three 10-second current records at the right of the figure illustrate the A $\beta$ channel activity 10 minutes after the channel was exposed to peptide NA12. The channel continues to be active, although the number of opening events is reduced compared to the pattern of channel activity observed in the control traces at the left of the figure. The current amplitude histogram at the bottom of Figure 3 shows that peptide NA12 reduces the number of observations of the most frequent peak values $(1.0,1.8,3.0$, 4.2 , and $5.5 \mathrm{pA}$ ). Addition of the native sequence peptide NA7 can complement the effect of NA12 (H13A) by completely blocking the $A \beta$ channel. As shown in Figure 4, the larger current peaks observed in $\mathrm{A} \beta$ alone are blocked by NA12 (H13A). Addition of native sequence peptide NA7 promptly eliminates the remainder of the current activity. The current amplitude histogram at the bottom of Figure 4 shows that NA12 blocks the current peak at 12.5 $\mathrm{pA}$ and increases the number of current events of 4.9 and $2.5 \mathrm{pA}$. A few minutes after the addition of NA7, the A $\beta$ channel activity is reduced to the smallest $2.2 \mathrm{pA}$ current event.

$\mathrm{A} \beta$ ion channel electrical activity also became partially reduced in the presence of peptide NA14 (H13K), as shown in the experiment illustrated in Figure 5. The current amplitude histogram at the bottom of Figure 5 reveals an increase in the number of observations corresponding to the small and intermediate current peaks at $0.4,1.2$ and $2.1 \mathrm{pA}$. On the other hand, the observations of the most frequent larger peak values of $3.0,4.1,5.2,6.4$ and 7.4. pA are either reduced or eliminated.

A $\beta$ channel conductance is not affected by the peptides missing both histidine residues

We found that addition of either NA13 (H13A; H14A) or NA15 (H13K; H14K) to membrane-bound $A \beta$ had no effect on $A \beta$ ion channel activity. Peptide NA13 was constructed with similar homology to the sequence of the NA7, except that histidine residues had been substituted with alanines. Peptide NA15 was constructed with similar homology to the sequence of the NA7, except that histidine residues had been substituted with lysines. The current records in Figures 6 and 7 depict the electrical activity of two Ab ion channels treated with the peptides NA13 and NA15. Figure 6 shows the results of an experiment where peptide NA13 (15 $\mu \mathrm{M})$ was added simultaneously to both the cis and the trans compartments. No change in the general pattern of the $A \beta$ ion channel activity was detected in current records taken 20 minutes later. The bottom panel shows the amplitude histogram of the current events corresponding to two minutes of continuous recording, before and 20 minutes after the incorporated $A \beta$ channels had been exposed to peptide NA13. The histogram reveals no difference in either the frequency or the amplitude of the main current events (1.0, 
2.1, 3.5 and $5.1 \mathrm{pA}$ ) occurring in control channels, or after peptide addition. Figure 7 shows the results of an experiment in which peptide NA15 (15 $\mu \mathrm{M})$ was added simultaneously to both the cis and the trans compartments. Again, no change in the general pattern of the $A \beta$ ion channel activity was detected in current records taken 20 minutes later. The amplitude histogram of the current events at the bottom of the figure does not reveal any significant difference in either the frequency or the amplitude $(0.3,1.0,1.7$, $2.4,3.2,4.2$ and $5.2 \mathrm{pA}$ ) of the main current events originating from the channels in control and after peptide treatment.

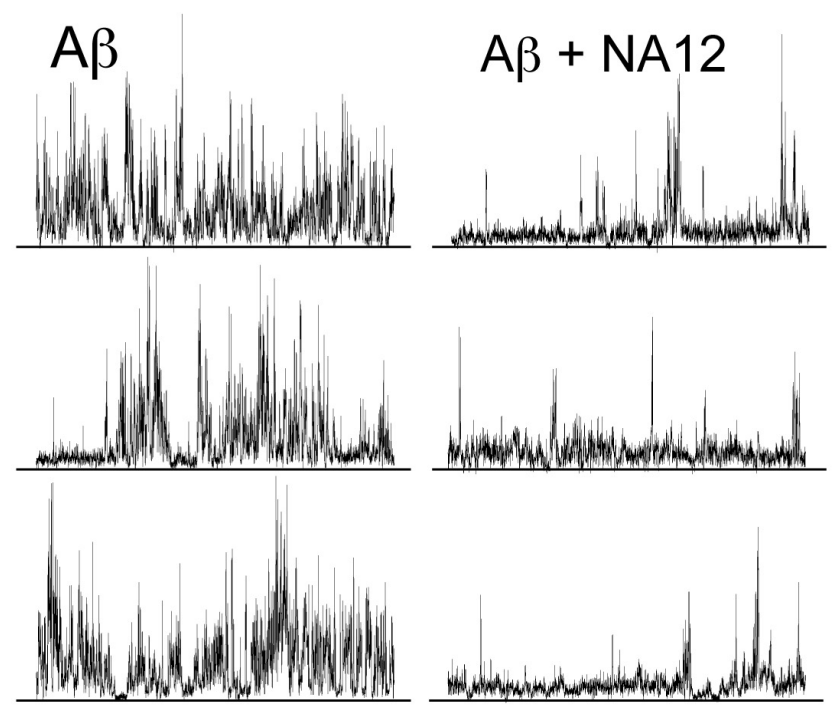

$2 \mathrm{pA}$

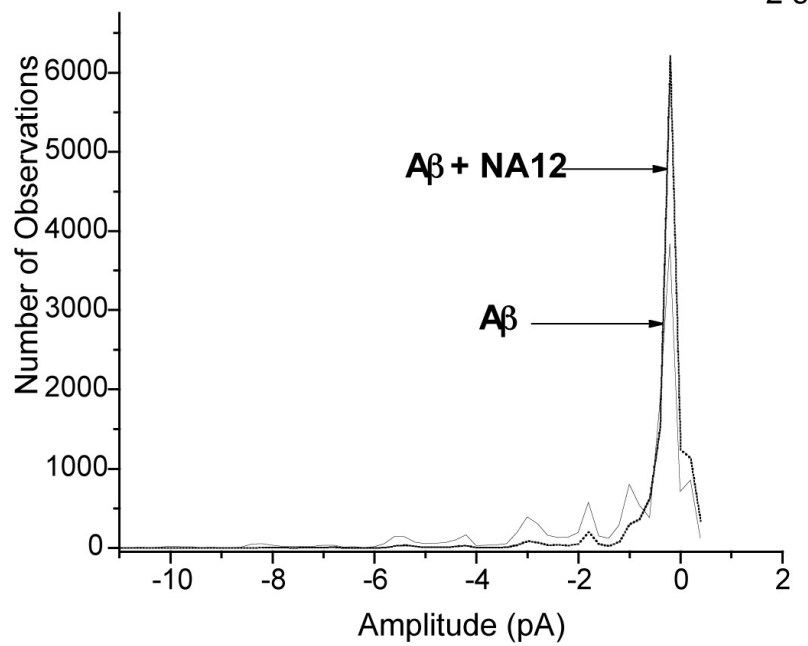

Figure 3. A $\beta$ channel conductance is mildly affected by the peptide NA12. A $\beta$ ion channel electrical activity prior to addition of NA12 (H13A, $7 \mu \mathrm{M})$ is shown in three left records. Twenty minutes after addition of the peptide (three right records) the channel continues to be active, although the number of opening events is reduced. The amplitude histograms at the bottom of the figure analyze the current events before and after the incorporated $A \beta$ channel has been exposed to NA12. The most frequent peak values of 1.0, 1.8, 3.0, 4.2 and $5.5 \mathrm{pA}$ are reduced after the addition of peptide NA12. 
$A \beta$

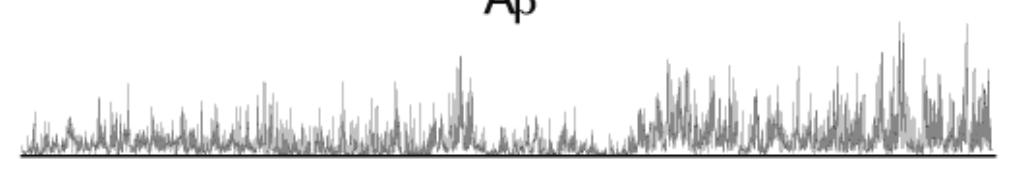

$\mathrm{A} \beta+\mathrm{NA} 12$

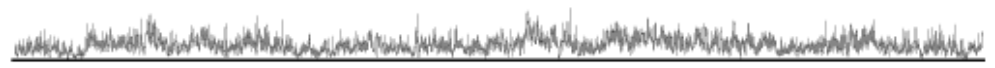

$\mathrm{A} \beta+\mathrm{NA} 12$ \& NA7, 3 min.

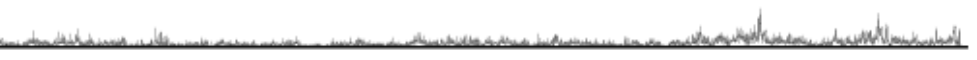

$\mathrm{A} \beta+\mathrm{NA} 12$ \& NA7, $19 \mathrm{~min}$.

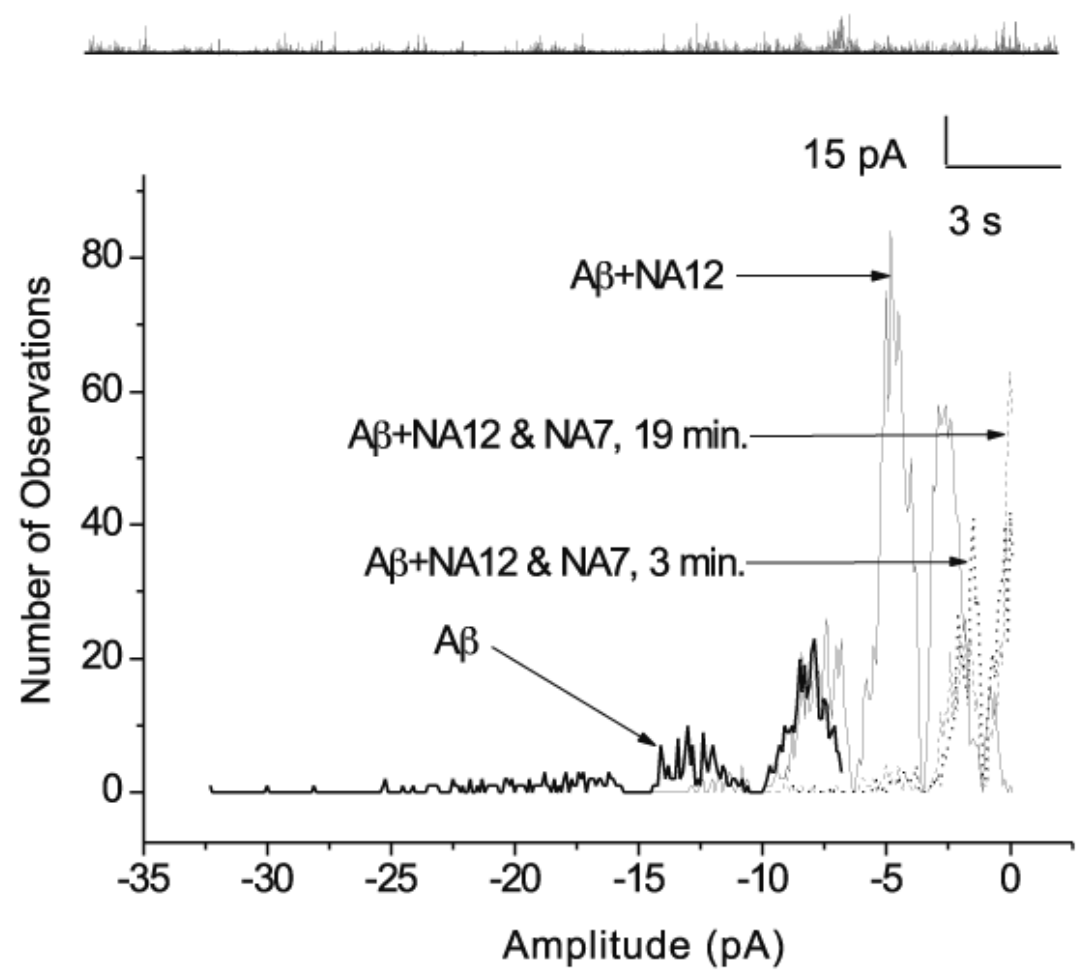

Figure 4. The inhibitory peptide NA7 blocks residual currents left by the less active peptide NA12. The normal $A \beta$ ion channel electrical activity is shown in the top current record. Ten minutes after addition of the peptide NA12 (H13A, $7 \mu \mathrm{M})$ the channel continues to be active, although the largest opening events are reduced (second current record). Addition of NA7 promptly eliminates the remainder of the activity (two bottom records). The amplitude histograms at the bottom of the figure analyze the current events before and after the incorporated $A \beta$ channel has been exposed to NA12 and to NA12 plus NA7. The current peak values larger than $12.5 \mathrm{pA}$ are reduced after the addition of peptide NA12. Addition of NA7 reduces the activity to occasional $1.5 \mathrm{pA}$ events. 

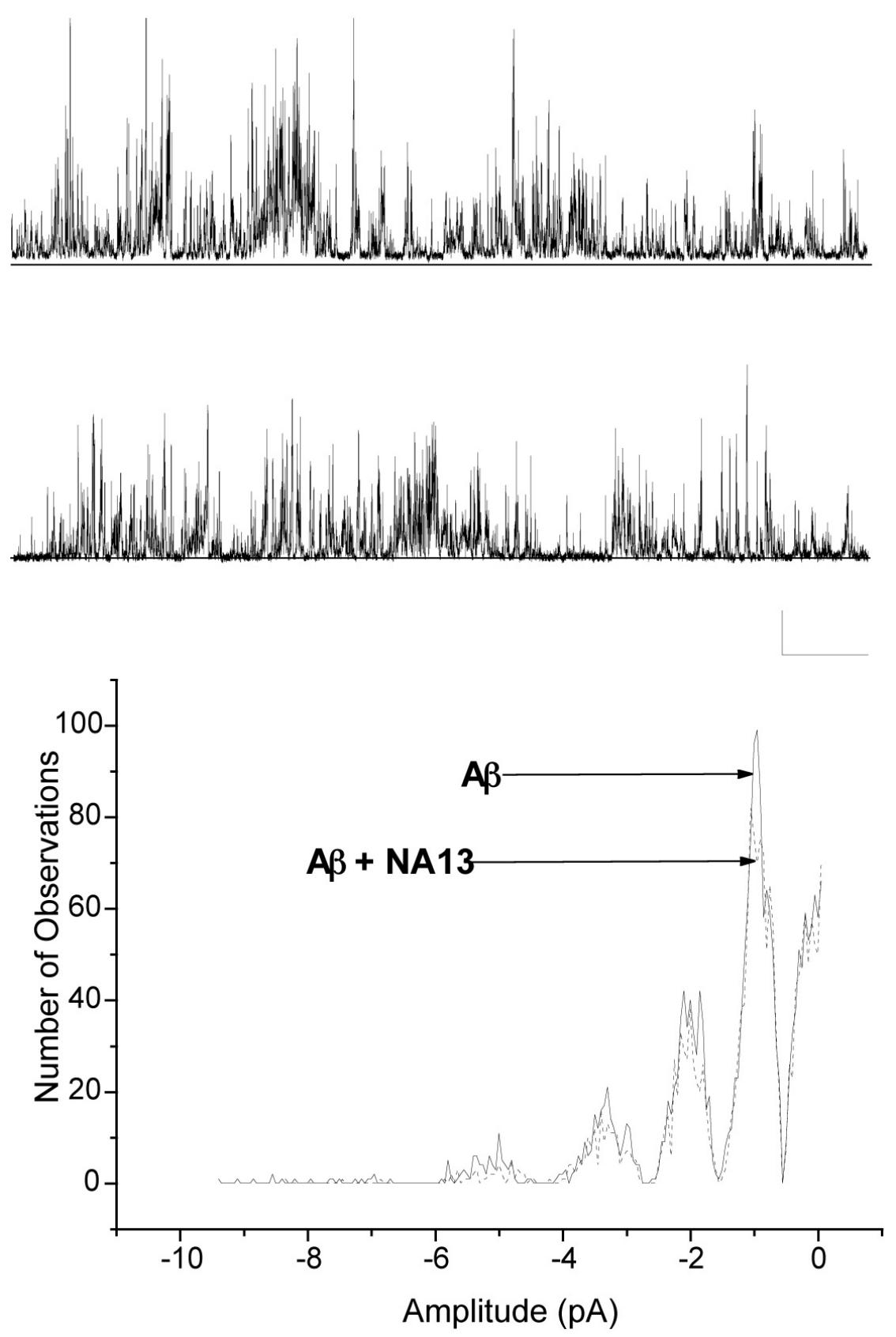

Figure 5. A $\beta$ channel conductance is not affected by the peptide NA13 (H13A; H14A). A $\beta$ ion channel electrical activity taken before (top record) and 20 minutes after the addition of NA13 (15 $\mu \mathrm{M})$ (bottom record). No change in the general pattern of the $A \beta$ ion channel activity is detected. The amplitude histograms at the bottom of the figure, analyze the current events during two minutes of continuous recording, before and after the incorporated $A \beta$ channels have been exposed to NA13. No differences are observed upon addition of the peptide in the frequency or the amplitude of the main current events $(1.0,2.1,3.5$ and $5.1 \mathrm{pA})$. 


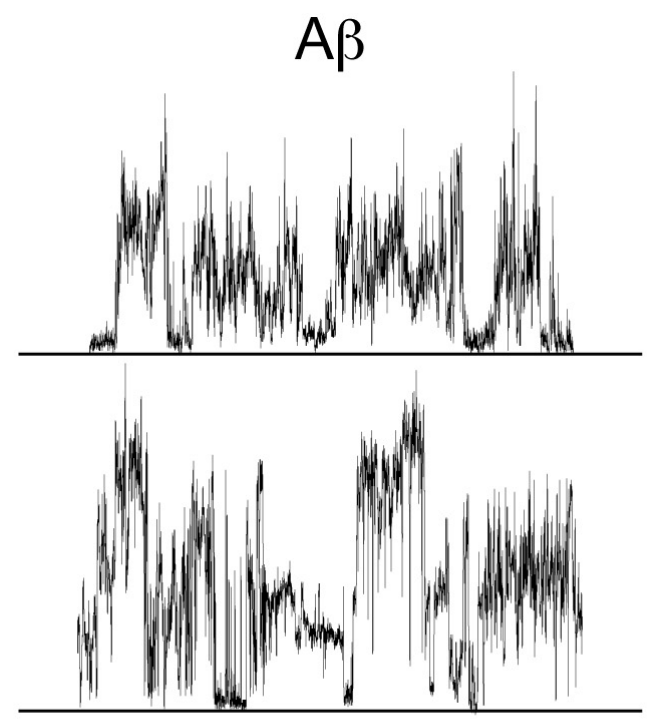

$A \beta+N A 14$
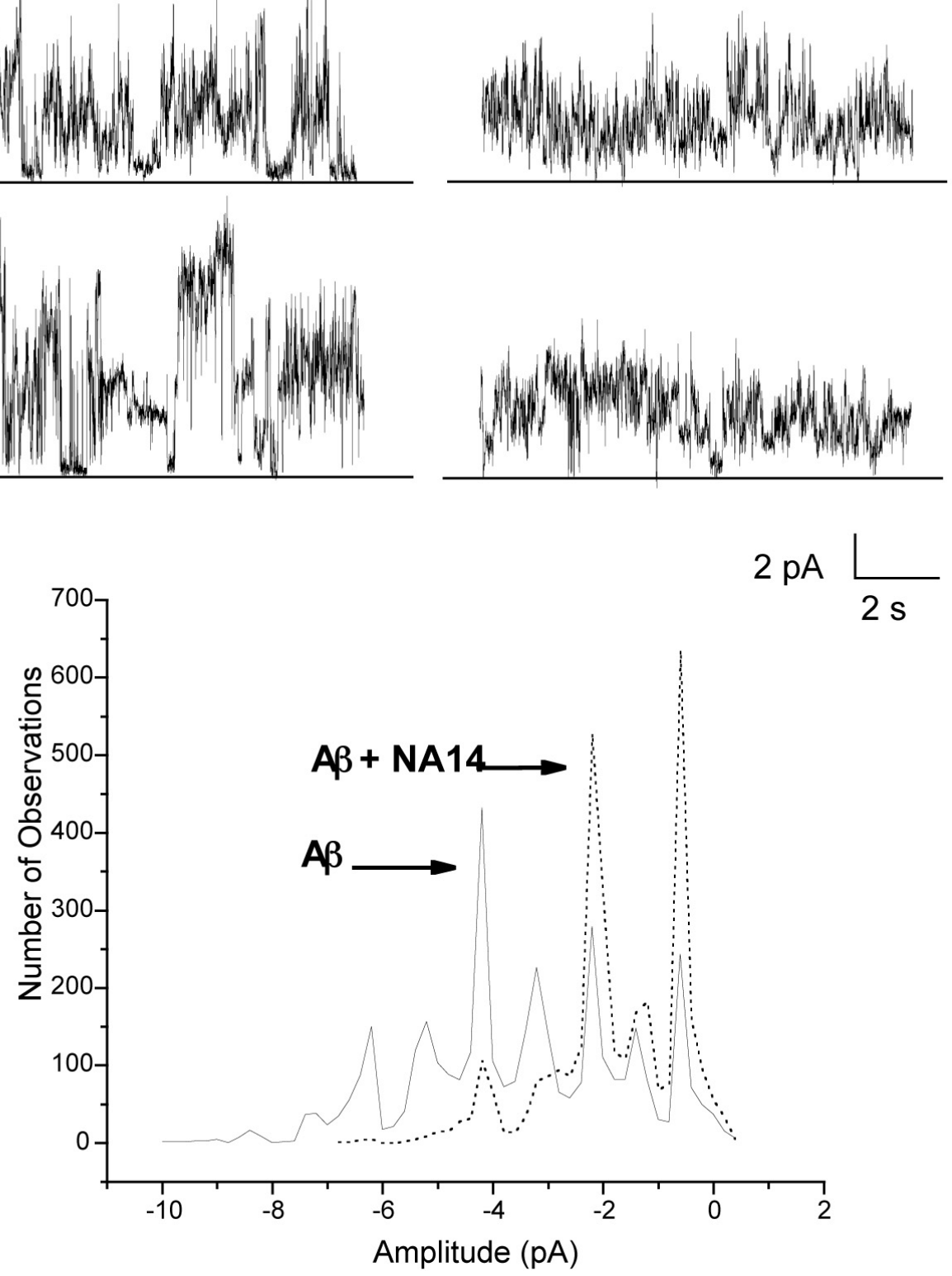

Figure 6. A $\beta$ channel conductance is mildly affected by the peptides NA14. A $\beta$ ion channel electrical activity prior to addition of NA14 $(\mathrm{H} 13 \mathrm{~K}, 7 \mu \mathrm{M})$ to the cis compartment is shown in two left records. Twenty minutes after addition of the peptide (two right records), the channel continues to be active, although the distribution of opening events is altered. The amplitude histograms at the bottom of the figure analyze the current events before and after the incorporated $A \beta$ channel has been exposed to NA14. There is an increase in the number of the small and intermediate current peaks at $0.4,1.2$ and $2.1 \mathrm{pA}$. On the other hand, the most frequent larger peak values of 3.0, 4.1, 5.2, 6.4 and 7.4. pA are either reduced or eliminated. 

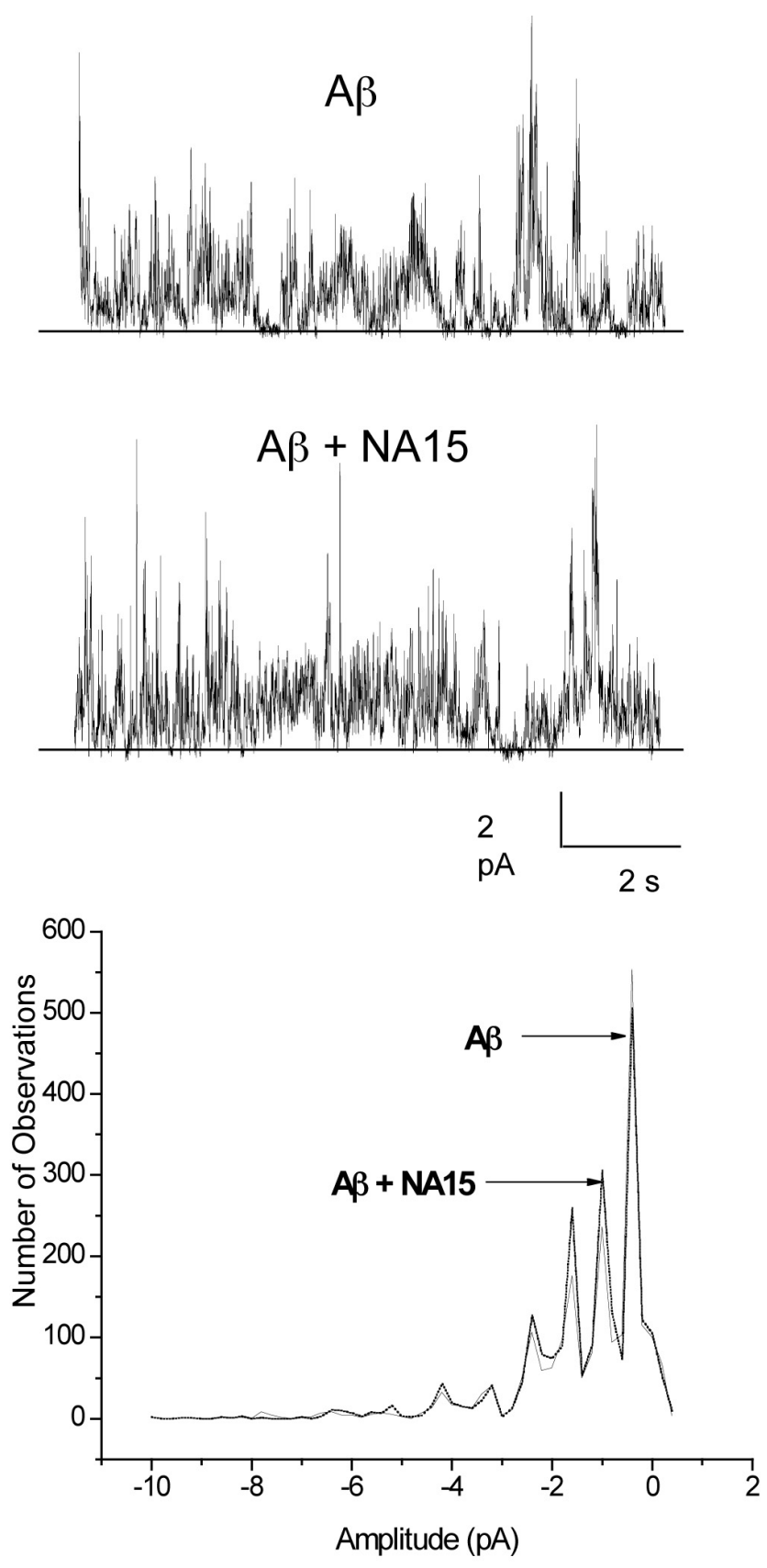

Figure 7. A $\beta$ channel conductance is not affected by the peptide NA15 (H13K; H14K). A $\beta$ ion channel electrical activity taken before (top record) and 20 minutes after the addition of NA15 $(15 \mu \mathrm{M})$ (bottom record). No change in the general pattern of the $A \beta$ ion channel activity is detected. The amplitude histograms at the bottom of the figure analyze the current events during two minutes of continuous recording, before and after the incorporated $A \beta$ channels have been exposed to NA15. No significant difference is detected in either the frequency or the amplitude of the main current events $(0.3,1.0,1.7,2.4,3.2,4.2$ and $5.2 \mathrm{pA})$, before or after the peptide addition. 
Native sequence peptide NA7 protects cells from $A \beta$ cytotoxicity

To test the hypothesis that $A \beta$ channel activity might be responsible for $A \beta$ cytotoxicity, we examined the ability of channel blocker peptide NA7 to preserve cells from $A \beta$-induced cell death. $A \beta$ has been reported to form typical $A \beta$ channels in plasma membranes of intact cells (Kawahara et al., 1997; Bathia et al., 2000; Zhu et al., 2000; Lin et al., 2001; Lee et al., 2002; Arispe and Doh, 2002, Simakova and Arispe, 2006). We therefore incubated PC12 cells in a medium containing $A \beta$ alone or $A \beta$ plus the different test peptides. Cell viability was evaluated 72 hours later. Figure 8A shows the viability of PC12 cells observed after three days of incubation in the presence of $A \beta$ (15 $\mu \mathrm{M})$ and $\mathrm{A} \beta$ plus the peptides NA7, NA12, NA13, NA14, and NA15 (16 $\mu \mathrm{g} / \mathrm{mL})$. The addition of $A \beta$ alone reduced the cell viability to $62 \%$ of the control value. However, the addition of $\mathrm{A} \beta$ plus native sequence NA7 (H13; H14) completely protected the cells from $A \beta$ toxicity. By contrast, the percentage of cells incubated in media containing $A \beta$ plus either NA12, NA13, NA14, or NA15 showed levels significantly similar to that observed in cells grown in medium containing $\mathrm{A} \beta$ alone. The results of a dose-response experiment to evaluate the capacity for protection of the five different peptides against $A \beta$ cytotoxicity is shown in Figure 8B. Only peptide NA7 was able to fully protect PC12 cells against $\mathrm{A} \beta(15 \mu \mathrm{M})$ toxicity at concentrations higher than $4 \mu \mathrm{g} / \mathrm{ml}$ and with $50 \%$ protection at less than $1 \mu \mathrm{g} / \mathrm{mL}$. The peptides NA12 (H13A), NA13 (H13A; H14A), NA14 (H13K), or NA15 (H13K; $\mathrm{H} 14 \mathrm{~K}$ ) did not show protection even at concentrations as high as $64 \mu \mathrm{g} / \mathrm{mL}$ (data not shown).

\section{DISCUSSION}

The data presented here demonstrate that a native peptide segment, NA7, from the predicted mouth of the $A \beta$ channel pore, is able to both block $A \beta$ channel activity and protect cells from $A \beta$ cytotoxicity. By contrast, replacement of histidines at position
13 and 14 by either a hydrophobic residue (alanine) or a cationic residue (lysine) results in the loss of both activities. These data thus support the hypothesis that the ion channel activity of $A \beta$ contributes significantly to the cytotoxic properties of $A \beta$. To the extent that $A \beta$ cytotoxicity is responsible for cell death in Alzheimer's disease, these data support the "ion channel hypothesis" for AD. These data thus emphasize the potential value in using inhibition of $A \beta$ ion channel activity as an end point for $\mathrm{AD}$ drug discovery.

Histidines are among the most common amino acids in protein active or binding sites, and they are very common in metal binding sites (e.g., zinc). The imidazole groups on the side chain of histidine can act as both an acid and a base, i.e., it can both donate and accept protons under some conditions. This means that this amino acid side chain finds its way into considerable use in coordinating binding interactions between proteins. This may be the case for the two rings of histidine residues, $\mathrm{His}_{13}$ and $\mathrm{His}_{14}$, encircling one pore entrance of the predicted oligomeric channel structure in the membrane and mediating the binding to the complementary histidinecontaining peptides.

We have shown previously that the common feature in active $A \beta$ ion channel blocker peptides is that they all possess in their sequence the two histidine residues modeled to line the entry to the $A \beta$ pore. However, in order to block the ionic current by interaction with $\mathrm{A} \beta \mathrm{P}$ channels, an additional and complementary interaction is required (Arispe, 2004). The data presented here indicate that peptide NA7 is a very effective $A \beta$ ion channel blocker and that it possesses the necessary complementary chemistry to establish an effective interaction with $A \beta$. To test the essential role of the histidine in this interaction, we constructed similar peptides in which only the histidines were replaced. Our results show that not only the histidine residues are essential for blocking the channel, but that it appears that these residues are required to block A $\beta$ cytotoxicity. Thus, only the peptide that faithfully copies the $\mathrm{H}-\mathrm{H}$ dyad around the proposed pore domain both blocks $A \beta$ ion channel activity and protects against the $A \beta$ cytotoxicity. 

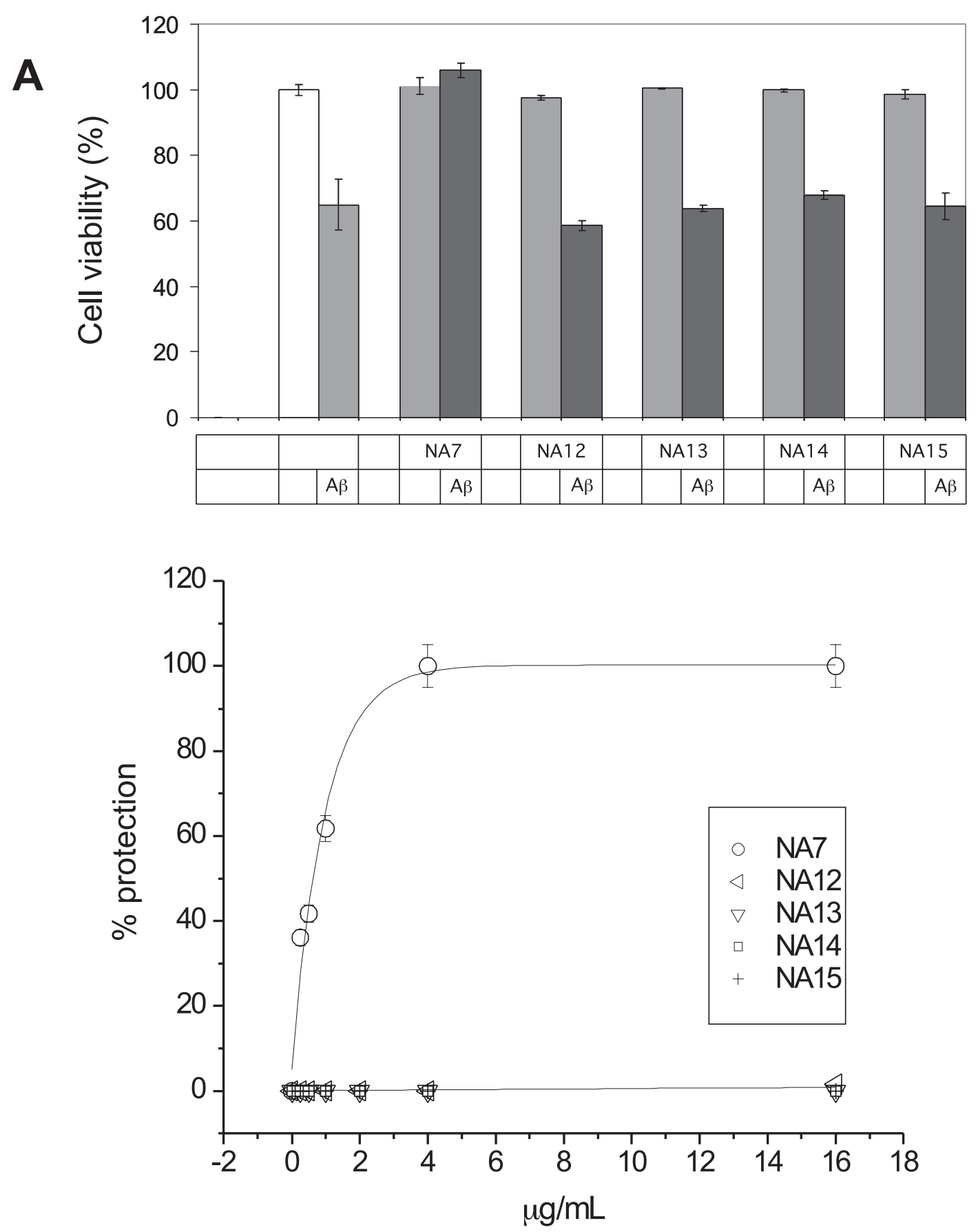

Figure 8. Native sequence peptide NA7 protects cells from A $\beta$ cytotoxicity. A. The viability of PC12 cells was determined after three days of incubation in the presence of $A \beta(15 \mu \mathrm{M})$ and $A \beta$ plus the peptides NA7, NA12, NA13, NA14, and NA15 $(16 \mu \mathrm{g} / \mathrm{mL})$ (dashed bars). A $\beta$ alone (dark bar) reduced the cell viability to $62 \%$ of the control value (white bar). A $\beta$ plus native sequence NA7 (H13; H14) completely protected the cells from A $\beta$ toxicity. By contrast, $A \beta$ plus either NA12, NA13, NA14, or NA15 showed cell viability levels significantly similar to the one obtained with $\mathrm{A} \beta$ alone $\left(* \mathrm{p}>5 \times 10^{-2}\right.$ compared to $\mathrm{A} \beta$ alone). Data are mean \pm S.E.M. $(\mathrm{n}=4)$. B. Doseresponse experiment to evaluate the capacity of protection of the five different peptides against $A \beta$ cytotoxicity. Only peptide NA7 was able to fully protect PC12 cells against A $\beta$ (15 $\mu \mathrm{M})$ toxicity at concentrations higher than $4 \mu \mathrm{g} / \mathrm{ml}$ and with $50 \%$ protection at less than $1 \mu \mathrm{g} / \mathrm{mL}$. 
Further support to the model that we previously proposed for the mechanism of action by which the blocker peptides affect the ionic flow (Arispe, 2004) is provided by the results from the residue substitution experiments described in this work. It is possible that when coordination between adjacent histidine-containing peptides and histidines in the mouth of the pore is established, the peptide blocks the entrance of the pore and consequently the flow of current through the channel. Our results show that when non-coordinating residues are substituted for the histidine residues, the peptides loose their effectiveness to both block the $\mathrm{A} \beta$ channel and prevent $A \beta$ cytotoxicity.

\section{ACKNOWLEDGEMENT}

This work was supported by a grant from the Alzheimer's Association of America.

\section{REFERENCES}

ARISPE N, ROJAS E, POLLARD HB (1993a) Alzheimer disease amyloid $\beta$ protein forms calcium channels in bilayer membranes: Blockade by tromethamine and aluminum. Proc Natl Acad Sci USA 90: 567-571

ARISPE N, ROJAS E, POLLARD HB (1993b) Giant multilevel cation channels formed by Alzheimer disease amyloid $\beta$ protein $[\mathrm{A} \beta \mathrm{P}-(1-40)]$ in bilayer membranes. Proc Natl Acad Sci USA 90: 10573-10577

ARISPE N, POLLARD HB, ROJAS E (1994a) The ability of Amyloid $\beta$-protein $[\mathrm{A} \beta \mathrm{P}(1-40)]$ to form $\mathrm{Ca} 2+$ channels provides a mechanism for neuronal death in Alzheimer's disease. Ann New York Acad Sc 747: 256-266

ARISPE N, POLLARD HB, ROJAS E (1994b) $\beta$-amyloid $\mathrm{Ca}^{2+}$-channel hypothesis for neuronal death in Alzheimer's disease. Mol Cell Biochem 140: 19-125

ARISPE N, POLLARD HB, ROJAS E (1996) $\mathrm{Zn}^{2+}$ interaction with Alzheimer amyloid $\beta$ protein calcium channels. Proc Natl Acad Sci 93: 1710-1715

ARISPE N, DOH M (2002) Plasma membrane cholesterol controls the cytotoxicity of Alzheimer's disease AbP(140) and AbP(1-42) peptides. FASEB J 16: 1526-1536

ARISPE NJ (2004) Architecture of the Alzheimer's A $\beta$ P ion channel. J Memb Biol 197(1): 33-48

BAHADI R, FARRELLY PV, KENNA BL, CURTAIN CC, MASTERS CL, CAPPAI R, BARNHAM KJ, KOURIE JI (2003) Cu2+-induced modification of the kinetics of A beta(1-42) channels. Am J Physiol Cell Physiol 285(4): C873-80

BATHIA R, LIN H, LAL R (2000) Fresh and globular amyloid protein (1-42) induces rapid cellular degeneration: Evidence for $\mathrm{A} \beta \mathrm{P}$ channel-mediated cellular toxicity. FASEB J 14: 1233-1243

DURRELL SR, GUY HR, ARISPE N, ROJAS E, POLLARD HB (1994) Theoretical models of the ion channel structure of amyloid- $\beta$-protein. Biophys J 67 : 2137-2145

GALDZICKI Z, FUKUYAMA R, WADHWANI K
RAPOPORT S, EHRENSTEIN G (1994) $\beta$-amyloid increases choline conductance of PC12 cells: Possible mechanism of toxicity in Alzheimer's disease. Brain Res 646: 332-3

HIRAKURA Y, LIN MC, KAGAN BL (1999) Alzheimer amyloid beta peptide 1-42 channels: Effect of solvent, $\mathrm{pH}$, and congo red. J Neurosci Res 57: 458-460

KAWAHARA M, ARISPE N, KURODA Y, ROJAS E (1997) Alzheimer's disease amyloid $\beta$-protein forms $\mathrm{Zn}^{2+}$-sensitive cation-selective channels across excited membrane patches from hypothalamic neurons. Biophysical J 73: 67-75

KOURIE JI, HENRY CL, FARRELLY P (2001) Diversity of amyloid beta protein fragment [1-40]-formed channels. Cell Mol Neurobiol 21(3): 255-84

LEE G, POLLARD HB, ARISPE N (2002) Annexin 5 and apolipoprotein E2 protect against Alzheimer's amyloid- $\beta$-peptide cytotoxicity by competitive inhibition at a common phosphatidylserine interaction site. Peptides 23: 12149-1263

LIN H, ZHU YJ, LAL R (1999) Amyloid $\beta$-protein (1-40) forms calcium-permeable $\mathrm{Zn}^{2+}$ sensitive channels in reconstituted lipid vesicles. Biochemistry 38: 11189-11196

LIN H, BHATIA R, LAL R (2001) Amyloid protein forms ion channels: Implications for Alzheimer's disease pathophysiology. FASEB J 15(13): 2433-2444

LIN MC, KAGAN B (2002) Electrophysiologic properties of channels induced by Ab25-35 in planar lipid bilayers. Peptides 23(7): 1215-1228

MATTSON MP, CHENG B, DAVIS D, BRYANT K, LIEBERBURG I, RYDEL RE (1992) $\beta$-amyloid peptides destabilize calcium homeostasis and render human cortical neurons vulnerable to excitotoxicity. J Neurosci 12: 379-389

MAURITS $R$, DE PLANQUE $R$ MENDES GP CONTERA SA, RIJKERS DTS, RYAN JF, WATTS A (2005) Interactions between transmembrane betaamyloid (1-40) and phosphatidylcholine bilayers. Abstracts, Biophysical Soc 49th Annual Meeting

MENDES GP, BERRY R, MORGAN H, SANDINSON M, WATTS A (2005) Simultaneous optical and electrical measurements on membrane proteins at the single molecule level. Abstracts Biophysical Soc 49th Annual Meeting

MICELLI S, MELELEO D, PICCIARELLI V, GALLUCC E (2004) Effects of sterols an $\beta$-amyloid peptide (A $\beta$ P 1-40) channel formation and their properties in planar lipid membranes. Biophys J 86: 2231-2237

POLLARD HB, ARISPE N, ROJAS E (1995) Ion channel hypothesis for Alzheimer's amyloid peptide neurotoxicity. Cell Mol Neurobiol 15: 513-526

QUIST A, DOUDEVSKI I, LIN H, AZIMOVA R, NG D, FRANGIONE B, KAGAN B, GHISO J, LAL R (2005). Anyloid ion channels: common structural link for protein-misfalding disease. Proc. Natl. Acad. Sci. USA. Jul 26; 102 (30): 104 27-32

RHEE SK, QUIST AP, LAL R (1998) Amyloid $\beta$-protein (1-42) forms calcium-permeable- $\mathrm{Zn} 2+$ sensitive channels. J Biol Chem 273: 13379-13382

SIMAKOVA O, ARISPEN (2006) Early and late cytotoxic effects of external application of the alzheimer's $A \beta$ result from the initial formation and function of ion channels. Biochemistry 45: 5907-5915

VARGAS J, ALARCON JM, ROJAS E (2000) Displacement currents associated with the insertion of Alzheimer disease amyloid $\beta$-peptide into planar bilayer membranes. Biophys J 79: 934-944

ZHU YJ, LIN H, LAL R (2000) Fresh and nonfibrillar amyloid $\beta$ protein (1-40) induces rapid cellular degeneration in aged human fibroblasts: Evidence for A $\beta$ P-channel-mediated cellular toxicity. FASEB J 14: 1244-1254 